\title{
ЕТАПИ РОЗВИТКУ СИСТЕМИ ВІЙСЬКОВО-МЕДИЧНОГО ПОСТАЧАННЯ В КОНТЕКСТІ ІСТОРІЇ БУДІВНИЦТВА ЗБРОЙНИХ СИЛ УКРАЇНИ
}

\author{
О. П. Шматенко ${ }^{1}$, М. В. Білоус ${ }^{1}$, Т. В. Приходько ${ }^{1}$, О. В. Галан ${ }^{1}$, В. В. Трохимчук², \\ Д. В. Дроздов ${ }^{1}$, Н. О. Тахтаулова ${ }^{1}$
}

Українська військово-медична академія ${ }^{1}$, Київ

Національна медична академія післядипломної освіти імені П. Л. Шупика², Київ maryvictory@ukr.net

ІНФОРМАЦІЯ

Надійшла до редакції / Received: 07.06.2019

Після доопрацювання / Revised: 27.08.2019

Прийнято до друку / Accepted: 29.08.2019

\section{Ключові слова:}

Збройні Сили України;

система медичного постачання; етапи розвитку та

реформування.

\section{АНОТАЦІЯ}

Мета роботи. Дослідження етапів становлення та розвитку системи військово-медичного постачання в контексті історії будівництва Збройних Сил України.

Матеріали і методи. Для досягнення поставленої мети дослідження проведено огляд вітчизняних наукових джерелта чинної нормативно-правової бази. Під час виконання дослідження використано методи інфрормаційного пошуку, систематизації, контент-аналізу, порівняння та узагальнення.

Результати й обговорення. При проведенні дослідження етапів становлення та розвитку системи військово-медичного постачання в контексті історії будівництва Збройних Сил України встановлено, що на момент створення Збройних Сил України військово-медична служба та система медичного постачання будувалась 3 використанням підходів Радянської Армії. 3'ясовано, що прийняття оборонної доктрини, зміна економічних засад в країні та обмеження ресурсів зумовили перехід до медичного забезпечення та постачання медичною технікою та майном за територіальним принципом. Це, у свою чергу, потребувало скорочення чисельності як Збройних Сил України, так і медичної служби до оптимальної кількості. Визначено, що недостатність бюджетного фрінансування протягом усіх років існування Збройних Сил України не дозволила в повному обсязі побудувати ефективну модель медичного постачання та провести технічне переоснащення медичної служби. Проведений ретроспективний аналіз еволюції органів управління медичною службою Збройних Сил України показав, що в періоди 1991 1994 рр. та 2005 - 2007 рр. існувало дублювання управлінської фрункції 3 медичного забезпечення в Міністерстві оборони України та Генеральному штабі Збройних Сил України. При цьому в період з 1998 - 2005 рр. управління медичним забезпеченням здійснював єдиний орган управління, що сприяло більш есрективному вирішенню питань медичного забезпечення.

Висновки. В статті проведено дослідження етапів становлення та розвитку системи військово-медичного постачання в контексті історії будівництва Збройних Сил України. Також визначено, що на сучасному етапі реалізується принцип єдиного органу управління медичною службою, що відповідає стандартам НАТО. На сьогодні розвиток системи медичного постачання Збройних Сил України орієнтований на інтеграцію в єдину ефективну систему логістичного забезпечення Збройних Сил України, яка фрункціонує

ISSN 2312-0967. Pharmaceutical review. 2019. № 3 
Фармацевтичний менеджмент, маркетинг та логістика

Pharmaceutical management, marketing and logistics

відповідно до норм та стандартів Альянсу. Таким чином, для вибору науково обґрунтованої моделі військово-медичного постачання в сучасних реаліях необхідним $€$ узагальнення історичного досвіду фрормування системи постачання медичним майном Збройних Сил України. Отже, предметом нашого подальшого дослідження є визначення еволюційних етапів розвитку управління потоковими процесами у системі медичного постачання Збройних Сил України.

Вступ. За результатами комплексного огляду сектора безпеки і оборони у 2015 році затверджено Стратегію національної безпеки України та Концепцію розвитку сектора безпеки і оборони України, де вперше у своїй історії Україна визначила курс на європейську інтеграцію та наміри щодо вступу до НАТО. Нова редакція Воєнної доктрини України [1] визначає завдання з підвищення обороноздатності держави шляхом ефективної реалізації нової єдиної воєнно-економічної, військово-промислової та військово-технічної політики, одним із напрямків якої є удосконалення системи забезпечення сил оборони, зокрема, фрінансування, логістики, охорони здоров'я військовослужбовців, військової освіти, мобілізаційної підготовки, в напрямку їх централізації та уніфікації [2].

Вищезазначене доводить, що система медичного забезпечення Збройних Сил (3С) України потребує подальшого удосконалення і розвитку в напрямку уніфікації та фрункціональної сумісності з медичними службами країн-членів НАТО [3]. Важливим елементом системи медичного забезпечення ЗС України є постачання медичною технікою і майном, що також потребує ресрормування в зв'язку із запровадженням єдиного логістичного підходу в забезпеченні ЗС України.

Слід зазначити, що форми та методи організації постачання медичним майном знаходяться у прямій залежності від загальних принципів медичного забезпечення військ, економічного розвитку країни та ії спроможностей щодо забезпечення сил оборони, розвитку вітчизняних фрармацевтичної та медичної галузей, а також впровадження новітніх наукових розробок у практичну сореру охорони здоров'я України.

Аналіз останніх досліджень військових вчених дозволив дійти висновку, що питання розвитку системи медичного забезпечення і постачання ЗС України, інших складових сил оборони є актуальними та мають широке коло обговорень.

Концептуальні підходи, принципи та основні положення до побудови сучасної системи управління медичним забезпеченням у контексті реформування 3С України розкриті у дослідженні таких вчених, як В. Я. Білий, В. В. Пасько, В. Б. Андронатій, А. В. Верба, В. Л. Савицький, М. І. Бадюк, О. М. Власенко, В. О. Жаховський, Е. М. Хорошун, В. І. Стриженко, О. Ю. Булах, О. О. Микита та інші.

Різним напрямкам впровадження основних засад медичного постачання у систему медичного забезпечення ЗС України присвячені роботи вітчизняних вче- них П. С. Сироти, В. В. Трохимчука, О. П. Шматенка, І. Г. Гринчука, В. С. Гульпи, С. Г. Убогова, Р. Л. Притули, А. Г. Голуба, А. М. Соломенного та інших.

Проте, незважаючи на наявну певну кількість праць наукового та практичного спрямування, досі не був проведений ретроспективний аналіз розвитку системи військово-медичного постачання у взаємозв'язку з етапами будівництва ЗС України, що і зумовило проведення даного дослідження. Адже для вибору науково обґрунтованої моделі військовомедичного постачання в сучасних реаліях необхідним $€$ узагальнення історичного досвіду фрормування системи постачання медичним майном ЗС України.

Таким чином, метою публікації є дослідження етапів становлення та розвитку системи військово-медичного постачання в контексті історії будівництва ЗС України.

Матеріали і методи. Для досягнення поставленої мети дослідження проведено огляд вітчизняних наукових джерел та чинної нормативно-правової бази. Під час виконання дослідження використано методи інсрормаційного пошуку, систематизації, контент-аналізу, порівняння та узагальнення.

Результати й обговорення. 24 серпня 1991 року Верховна Рада України прийняла Постанову «Про військові формування в Україні», якою було покладено початок будівництва Збройних Сил України як важливого інституту держави і невід'ємного елемента ії воєнної організації. Історію будівництва ЗС можливо поділити на такі етапи:

I - формування основ ЗС України (1991-1996рр.);

II - подальше будівництво ЗС України (19972000 pp.);

III - ресоормування 3С України (2001-2005 рр.);

IV - розвиток 3С України (2006-2011рр.).

З 2012 до 2017 р. планувалося здійснити новий етап військової реформи, однак у зв'язку з агресією Російської Федерації виконання заходів даного етапу було призупинено [4].

Станом на 24 серпня 1991 року на території України дислокувались: три загальновійськові і дві танкові армії, армійський корпус, чотири повітряні армії, окрема армія Протиповітряної оборони, ракетна армія, Чорноморський фллот, два вузли Системи попередження про ракетний напад та інші військові формування із загальною чисельністю близько 900 тисяч осіб [5]. Восени - взимку 1991 року були підготовлені й затверджені важливі документи, що стали норма-

ISSN 2312-0967. Фармацевтичний часопис. 2019. № 3 
тивно-правовою базою фрормування 3С України, серед яких і Концепція оборони і будівництва 3С, якою передбачалося, що Україна поступово, з урахуванням усіх фракторів національної безпеки, реалізуватиме намір стати в майбутньому нейтральною, без'ядерною державою, яка не братиме участі у військових блоках, натомість дотримуватиметься усіх договорів і угод щодо незастосування ядерної зброї.

У жовтні 1993 року Верховна Рада України прийняла Постанову «Про загальну структуру, чисельність та матеріально-технічне забезпечення ЗС України», де було визначено чисельність Збройних Сил 455 тис. військовослужбовців та затверджено Воєнну доктрину України, що визначила необхідність приведення системи оборони країни відповідно до сучасних геополітичних і геостратегічних умов. Подальше фрормування 3С України супроводжувалося значним скороченням чисельності особового складу та озброєнь [4].

У січні 1997 року Президент України затвердив Державну програму будівництва та розвитку 3С на період до 2005 року і так розпочався другий етап військового будівництва. 31998 року запроваджено нову систему військово-адміністративного розподілу території України - замість військових округів було утворено оперативні командування, що фрункціонально стали оперативно-стратегічними об'єднаннями, призначеними для виконання як у мирний, так і у воєнний час оперативних, мобілізаційних завдань і завдань територіальної оборони, а також технічного, тилового, медичного та інших видів забезпечення військ, що знаходяться на їхніх територіях, незалежно від відомчої підпорядкованості. Згідно з Постановою Верховної Ради України від 22 грудня 1998 року була затверджена чисельність 3С: станом на 31 грудня 1998 року - 320 тис. військовослужбовців і 100 тис. працівників; на 31 грудня 1999 року - 310 тис. військовослужбовців і 90 тис. працівників.

3 початку 1999 року було здійснено перехід на нову систему тилового забезпечення за територіальним принципом, що дозволило уніфікувати і скоротити кількість тилових структур, забезпечити інтеграцію ресурсів, сил та засобів тилу і комплексне їхнє використання в інтересах усіх структур 3С України [4].

Медичне забезпечення і медичне постачання 3С України при їхньому створенні базувалось на організаційних засадах, сорормованих в медичній службі Радянської Армії, фррагментом якої вони власне і були. Проте стрімкі зміни, які відбувались протягом 1991 - 2001 рр. в масштабах держави і Збройних Сил, визначили напрямки і шляхи перетворень в системі військової охорони здоров'я. Головними напрямками реформи в зазначений період були: орієнтація на оборонну війну обмежених масштабів і обмеженої тривалості; обмеженість ресурсів, які може виділити загальнодержавна система охорони здоров'я для відмобілізування і підтримання військово-медичної служби в працездатному стані; максимальне використання загальнодержавної мережі лікувальних закладів для поранених і хворих військовослужбовців; обмеженість власне військових медичних закладів дійсно необхідною кількістю; ліквідація відомчого підходу в системі силових міністерств та відомств і запровадження територіального принципу медичного забезпечення військ не тільки у мирний, але й у воєнний час. Тому, згідно з Державними програмами будівництва та розвитку ЗС України, проводилось реформування військово-медичної служби - здійснювався перехід органів управління медичної служби, медичних закладів і підрозділів на нові організаційноштатні структури, відбувалось планове скорочення медичних частин та закладів й чисельності особового складу. У результаті цих заходів було скорочено 128 військово-медичних частин, чисельність особового складу медичної служби ЗС України зменшилась на $62 \%$ [6].

У 2000 році опрацьовані Військово-медична доктрина України та Концепція військово-медичної служби, на основі яких і почала фрормуватися модель медичного забезпечення військ у складі трьох управлінських вертикалей - лікувально-профілактичної, санітарно-епідеміологічної, медичного постачання і двох систем - підготовки військово-медичних кадрів і науково-технічної діяльності.

Вертикаль медичного постачання включала 2 Центральні медичні склади, 4 регіональні та 4 територіальні медичні склади, 5 Управлінь госпітальних баз, значну кількість медичних депо, 38 аптек військових госпіталів та інших лікувальних закладів, а також аптеки військових частин і з'єднань. В зазначений період медичне постачання здійснювалось при вкрай обмеженому бюджетному фінансуванні - в 2000 році фрінансування дозволило провести закупівлю лише 4 \% від потреби медичного майна, в 2001 році - лише 3,5 \%. Тому виникла необхідність поєднання принципів централізації та децентралізації централізовано закуповувались великі партії лікарських засобів і устаткування, а децентралізовано предмети, необхідні в обмежених кількостях або для екстрених потреб. Такий стан фрінансування вимагав від начальників медичних закладів і установ запровадження економічно доцільних механізмів самофрінансування та подальшого розширення обсягу надання платних послуг з метою забезпечення необхідного рівня медичної допомоги і лікування хворих [6].

Період виконання Державної програми ресрормування та розвитку 3С України (2001 - 2005 рр.). можна вважати третім етапом будівництва 3С України. Загальна чисельність особового складу 3С України станом на кінець 2005 року складала 245 тис. осіб, у тому числі 180 тис. військовослужбовців. Співвідношення між видами Збройних Сил становило: Сухопутні війська - до 40 \%; Повітряні Сили - до $24 \%$; Військово-Морські Сили - до 8 \%; органи військового

ISSN 2312-0967. Pharmaceutical review. 2019. № 3 
управління, військові навчальні заклади, установи до 28 \%. Відбулися суттєві зміни у структурі Збройних Сил та системі управління військами, зокрема, був запроваджений фрункціональний принцип побудови Збройних Сил та їх застосування. Здійснено розподіл функцій та повноважень між Міністерством оборони України та Генеральним штабом 3С України [4].

У медичній службі ЗС України в період до 2003 року продовжувалась реалізація системи управлінських вертикалей, запропонованої начальником Головного військово-медичного управління МО України Білим В. Я., і як наслідок, розподіл усієї території дислокації військ на зони відповідальності військових госпіталів, які, у свою чергу, також були структуровані за функціональними і територіальними рівнями та за рівнями надання медичної допомоги. Проте зазначена система виявилась слабо адаптованою до швидких змін кількісних характеристик особового складу військово-медичної служби у зв'язку з рефрормуванням і загальним скороченням 3С України, оскільки рефрормування однієї госпітальної ланки іноді порушувало усю вертикаль, тому створена система невдовзі була зруйнована [7].

Четвертий етап будівництва Збройних Сил України розпочався у 2006 році з виконання завдань, визначених Державною програмою розвитку ЗС України на 2006-2011 роки. Головною подією, яка визначально вплинула на безпекову ситуацію, стало оголошення Законом України «Про засади внутрішньої і зовнішньої політики» (2010р.) позаблокового статусу України, що означав її неучасть у військово-політичних союзах, пріоритетність участі у вдосконаленні та розвитку європейської системи колективної безпеки, продовження конструктивного партнерства з Організацією Північноатлантичного договору та іншими військово-політичними блоками [4].

Загалом протягом 2006 - 2011 років удосконалено структуру та скорочено чисельність Збройних Сил, рефрормовано систему військової освіти, кадрового і медичного забезпечення, розширено сферу діяльності міжнародного військового співробітництва. Чисельність Збройних Сил зменшено 3245 тис. до 192 тис. осіб. Питому вагу бойових з'єднань і військових частин доведено до 47 \%, військових частин і підрозділів логістики, військових навчальних закладів, установ та організацій - до 53 \%. Було прийнято на озброєння 112 нових і модернізованих зразків озброєння та військової техніки. Закуплено понад 1300 нових і модернізованих основних зразків озброєння та військової техніки та понад 7 тис. одиниць іншого військового майна [4].

Відповідно до Програми розвитку системи медичного забезпечення ЗС України на 2006 - 2011 рр., затвердженої наказом Міністра оборони України від 24.11.2006 р., відбувалось подальше удосконалення функціональних і структурних складових військової медицини шляхом впровадження територіального принципу медичного забезпечення: створено Військово-медичні клінічні центри - як органи управління медичним забезпеченням оперативного рівня, при ВМКЦ сорормовано мобільні військові госпіталі, транспортно-евакуаційні підрозділи [7, 8]. В цей період було нормативно закріплено порядок організації медичного постачання за територіальним принципом через Військово-медичні клінічні центри регіонів [9].

Разом з тим, актуальною проблемою залишалось хронічне недофрінансування потреб медичної служби. В період з 2005 до 2007 р. фрінансування медичної служби на придбання лікарських засобів, перев'язувальних засобів та іншого витратного майна складало близько 25 \% від потреби. На 2012 р. на закупівлю лікарських засобів було заплановано 85,68 млн грн, що становило 61,7 \% від потреби, проте вже в грудні 2011 р. призначення були зменшені до 55,6 млн грн, що становило лише 40 \% від потреби [10].

У 2013 році вперше за останні роки, на потреби оборони були передбачені видатки менше 1 \% ВВП, що не дозволило в повному обсязі забезпечити ресурсні потреби Збройних Сил. Продовжувалося скорочення особового складу та оптимізація всіх ланок військового управління. На кінець 2013 року чисельність Збройних Сил України становила 165,5 тис. осіб, у тому числі - 120,9 тис. військовослужбовців [4].

Розвиток подій у 2014 році показав, що існує необхідність проведення докорінних змін у підходах до фрормування засад державної політики. Тому було відмінено позаблоковий статус України, призупинено виконання заходів Державної комплексної програми ресрормування і розвитку 3С України на період до 2017 року, як такої, що не відповідає сучасній воєннополітичній обстановці та не забезпечує спрямування наявних державних ресурсів на пріоритетні напрямки розвитку Збройних Сил. Протягом року за підсумками мобілізаційного розгортання військ було сформовано 4 бригади та 29 батальйонів територіальної оборони, які згодом були переформовані в окремі мотопіхотні батальйони. На кінець 2014 року після проведених організаційних заходів чисельність Збройних Сил становила 250,0 тис. осіб, у тому числі 204,0 тис. військовослужбовців [4].

Подальший ретроспективний пошук, вивчення наукових та нормативно-правових джерел [2 - 11] спонукає до більш детального аналізу, систематизації наукової інорормації з виокремленням еволюційних етапів розвитку органів управління медичною службою зС України, яке знайшло своє відображення у таблиці 1.

Отже, проведений аналіз еволюції органів управління медичною службою ЗС України показав, що в періоди 1991 - 1994 рр. та 2005 - 2007 рр. існувало дублювання управлінської фрункції з медичного забезпечення в Міністерстві оборони України та Генеральному штабі зС України. При цьому, в період 3

ISSN 2312-0967. Фармацевтичний часопис. 2019. № 3 
Фармацевтичний менеджмент, маркетинг та логістика Pharmaceutical management, marketing and logistics

Таблиця 1

Еволюція органів управління медичною службою Збройних Сил України

\begin{tabular}{|c|c|c|c|c|}
\hline $\begin{array}{l}\text { Періоди } \\
\text { (роки) }\end{array}$ & Програма & $\begin{array}{l}\text { Генеральний штаб } \\
\text { ЗС України }\end{array}$ & $\begin{array}{l}\text { Міністерство оборони } \\
\text { України }\end{array}$ & $\begin{array}{l}\text { Кількість закладів / } \\
\text { чис. особов. складу }\end{array}$ \\
\hline \multicolumn{5}{|c|}{ Фрагмент системи медичного забезпечення СРСР і його ЗС до 1991 р. } \\
\hline $\begin{array}{l}1991- \\
1996\end{array}$ & $\begin{array}{l}\text { Формування основ ЗС } \\
\text { України }\end{array}$ & $\begin{array}{l}\text { Військово-медичне } \\
\text { управління штабу } \\
\text { Тилу ЗС України } \\
\text { (08.1991-05.1994); } \\
\text { Центральне ВМУ } \\
\text { Тилу ЗС України } \\
\text { (05.1994-10.1994); } \\
\text { Головне ВМУ ГШ ЗС } \\
\text { України (10.1994) }\end{array}$ & $\begin{array}{l}\text { Управління охорони здоров'я } \\
\text { МО України (10.1994-1998) }\end{array}$ & $\begin{array}{l}\text { 200/49000; } \\
107 / 21000\end{array}$ \\
\hline $\begin{array}{l}1997- \\
2000\end{array}$ & $\begin{array}{l}\text { Програма будівни- } \\
\text { цтва та розвитку 3С } \\
\text { України }\end{array}$ & & $\begin{array}{l}\text { Головне ВМУ МО України } \\
\text { (1998-2004) }\end{array}$ & $77 / 7957$ \\
\hline $\begin{array}{l}2000- \\
2005\end{array}$ & $\begin{array}{l}\text { Державна програма } \\
\text { будівництва та розви- } \\
\text { тку ЗС України на пе- } \\
\text { ріод до } 2005 \text { р. }\end{array}$ & & $\begin{array}{l}\text { Департамент з питань охоро- } \\
\text { ни здоров'я МО України } \\
\text { (2004-2005) }\end{array}$ & $\begin{array}{l}77 / 7948 \\
75 / 7932 \\
73 / 6644\end{array}$ \\
\hline $\begin{array}{l}2006- \\
2011\end{array}$ & $\begin{array}{l}\text { Державна програма } \\
\text { розвитку 3С України } \\
\text { на 2006-2011 роки }\end{array}$ & $\begin{array}{l}\text { Центральне військо- } \\
\text { во-медичне управлін- } \\
\text { ня 3С України } \\
\text { (11.2011) }\end{array}$ & $\begin{array}{l}\text { Департамент охорони } \\
\text { здоров'я МО України (2005- } \\
\text { 2009); } \\
\text { Військово-медичне управлін- } \\
\text { ня МО України (2009); } \\
\text { Головне військово-медичне } \\
\text { управління МО України } \\
\text { (2009); } \\
\text { Військово-медичний департа- } \\
\text { мент МО України (2009) }\end{array}$ & $\begin{array}{l}\text { 87/9996; } \\
\text { 90/10867; } \\
\text { 99/11356; } \\
86 / 11180\end{array}$ \\
\hline $\begin{array}{l}2011- \\
2017\end{array}$ & $\begin{array}{l}\text { Державна програма } \\
\text { ресрормування і роз- } \\
\text { витку ЗС України на } \\
\text { період до } 2017 \text { року }\end{array}$ & $\begin{array}{l}\text { Центральне військо- } \\
\text { во-медичне управлін- } \\
\text { ня 3С України (2011- } \\
\text { 2017) }\end{array}$ & $\begin{array}{l}\text { Військово-медичний департа- } \\
\text { мент МО України (2009- } \\
\text { 2018) }\end{array}$ & $\begin{array}{l}\text { 81/10849; } \\
\text { 83/11478 }\end{array}$ \\
\hline $\begin{array}{l}\text { Сучасний } \\
\text { етап : } \\
\text { з } 2016 \text { до } \\
\text { сьогодні }\end{array}$ & $\begin{array}{l}\text { Стратегічний оборон- } \\
\text { ний бюлетень України } \\
\text { (Указ Президента } \\
\text { України від } \\
\text { 06.06.2016 року } \\
\text { № 240/2016) }\end{array}$ & \multicolumn{2}{|c|}{ Головне військово-медичне управління } & $84 / 12980$ \\
\hline
\end{tabular}

1998 - 2005 рр. управління медичним забезпеченням здійснював єдиний орган управління, що сприяло більш ефективному вирішенню питань медичного забезпечення.

На сучасному етапі реалізується принцип єдиного органу управління медичною службою, що відповідає стандартам НАТО.

Узагальнення літературних джерел та власний досвід авторів показали, що система медичного постачання 3С України розвивалась відповідно до програм рефрормування 3С України.

Встановлено, що на момент створення 3С України військово-медична служба та система медичного постачання будувалась 3 використанням підходів Ра- дянської Армії. Прийняття оборонної доктрини, зміна економічних засад в країні та обмеження ресурсів зумовили перехід до медичного забезпечення та постачання медичною технікою та майном за територіальним принципом. Це, у свою чергу, потребувало скорочення чисельності як ЗС України, так і медичної служби до оптимальної кількості.

Недостатність бюджетного фрінансування протягом усіх років існування 3С України не дозволила в повному обсязі побудувати ефрективну модель медичного постачання та провести технічне переоснащення медичної служби.

Станом на сьогодні, сучасний розвиток системи медичного постачання ЗС України орієнтований на

ISSN 2312-0967. Pharmaceutical review. 2019. № 3 
Фармацевтичний менеджмент, маркетинг та логістика Pharmaceutical management, marketing and logistics

інтеграцію в єдину ефективну систему логістичного забезпечення ЗС України, яка фрункціонує відповідно до норм та стандартів НАТО [12 - 14].

Перехід до сучасних євроатлантичних підходів 3С України реалізується під пильним контролем держави. Саме державна програма реформування та розвитку 3С України на період до 2020 року, яка затверджена Указом Президента України від 29.12.2016 № 73/2017, передбачає створення єдиної ефективної системи логістики та удосконалення системи медичного забезпечення ЗС України відповідно до стандартів Альянсу [13]. Разом 3 тим, Концепція програми розвитку системи медичного забезпечення 3С України на період до 2020 року, яка опрацьована відповідно до вимог вищезазначеного нормативно-правового акту, передбачає передачу фрункцій медичного постачання до системи логістики ЗС України [14].

Висновки. 1. Проведено дослідження етапів становлення та розвитку системи військово-медичного постачання в контексті історії будівництва Збройних Сил України.

2. Встановлено, що на момент створення Збройних Сил України військово-медична служба та система медичного постачання будувалась 3 використанням підходів Радянської Армії.

3. З'ясовано, що прийняття оборонної доктрини, зміна економічних засад у країні та обмеження ресурсів зумовили перехід до медичного забезпечення та постачання медичною технікою та майном за територіальним принципом. Це, у свою чергу, потребувало скорочення чисельності як Збройних Сил Укра- їни, так і медичної служби до оптимальної кількості.

4. Визначено, що недостатність бюджетного фpiнансування протягом усіх років існування Збройних Сил України не дозволила в повному обсязі побудувати ефективну модель медичного постачання та провести технічне переоснащення медичної служби.

5. Проведений ретроспективний аналіз еволюції органів управління медичною службою Збройних Сил України показав, що в періоди 1991 - 1994 рр. та 2005 - 2007 рр. існувало дублювання управлінської функції з медичного забезпечення в Міністерстві оборони України та Генеральному штабі Збройних Сил України. При цьому в період з 1998 - 2005 рр. управління медичним забезпеченням здійснював єдиний орган управління, що сприяло більш есрективному вирішенню питань медичного забезпечення.

6. Встановлено, що на сучасному етапі реалізується принцип єдиного органу управління медичною службою, що відповідає стандартам НАТО. Станом на сьогодні, розвиток системи медичного постачання 3С України орієнтований на інтеграцію у єдину ефективну систему логістичного забезпечення 3С України, яка фрункціонує відповідно до норм та стандартів Альянсу.

У перспективі найближчих досліджень вбачаємо визначення еволюційних етапів розвитку управління потоковими процесами у системі медичного забезпечення Збройних Сил України.

Конфрлікт інтересів: відсутній.

Conflicts of interest: authors have no conflict of interest to declare.

\title{
STEPS OF THE MILITARY AND MEDICAL DEVELOPMENT SUPPLY SYSTEM IN THE CONTEXT OF THE HISTORY OF BECOMING AND EVOLVEMENT OF THE ARMED FORCES OF UKRAINE
}

\author{
O. P. Shmatenko ${ }^{1}$, M. V. Bilous ${ }^{1}$, T. V. Prikhodko ${ }^{1}$, O. V. Galan ${ }^{1}$, V. V. Trokhymchuk ${ }^{2}$, D.V. Drozdov ${ }^{1}$, \\ N. O. Takhtaulova ${ }^{1}$ \\ Ukrainian Military Medical Academy¹, Kyiv, \\ National Medical Academy of Postgraduate Education², Kyiv \\ maryvictory@ukr.net
}

The aim of the work. To study the stages of formation and development of military medical supply system in the context of building history of the Armed Forces of Ukraine.

Materials and Methods. To achieve the goal of the study, an analysis of domestic scientific sources and the current legal documents was conducted; methods of information retrieval, systematization, content analysis, comparison, generalization and modeling were used.

Results and Discussion. During the study of the stages of formation and development of military medical supply system in the context of the history of becoming and evolvement of the Armed Forces of Ukraine, it was established that at the time of the creation of the Armed Forces of Ukraine, the military medical service and the system of medical supplies were being constructed using the approaches of the Soviet Army.

It was clarified that the adoption of a defense doctrine, the change in economic conditions in the country and the limited resources led to the transition to medical care and the supply of medical equipment and property on a territorial basis.

This is also required separation losses of both the Armed Forces of Ukraine and the medical service to the optimal number. It was determined that the lack of budget financing during all the years of the existence of the Armed Forces of Ukraine did not allow to build an effective model of medical supplies and carry out technical re-equipment of the medical service fully. The retrospective analysis of the evolution of the medical service of the Armed Forces of Ukraine showed that in

ISSN 2312-0967. Фармацевтичний часопис. 2019. № 3 
1991-1994 and 2005-2007 it was a duplication of the management function of medical care in the Ministry of Defense of Ukraine and the General Staff of the Armed Forces of Ukraine. At the same time, in the period from 1998-2005, the management of medical care carried out a single governing body, which contributed to a more effective solution to the issues of medical care.

Conclusions. The stages of formation and development of the military-medical supply system in the context of the history of the construction of the Armed Forces of Ukraine are conducted in the article. It is also determined that at the present stage the principle of a unified medical service management body that meets NATO standards is implemented. As of today, the development of the medical supply system of the Armed Forces of Ukraine is aimed at integrating into a single effective logistic support system of the Armed Forces of Ukraine, which operates in accordance with the norms and standards of the Alliance. Thus, in order to choose a scientifically grounded model of military medical supply in modern realities, it is necessary to summarize the historical experience of the formation of a supply system of medical equipment to the Armed Forces of Ukraine. As a result, the subject of our further research is to determine the evolutionary stages in the management of streaming processes in the medical supply system of the Armed Forces of Ukraine.

Key words: the Armed Forces of Ukraine; the system of medical supplies; stages of development and reform.

\title{
ЭТАПЫ РАЗВИТИЯ СИСТЕМЫ ВОЕННО-МЕДИЦИНСКОГО СНАБЖЕНИЯ В КОНТЕКСТЕ ИСТОРИИ СТАНОВЛЕНИЯ И РАЗВИТИЯ ВООРУЖЁННЫХ СИЛ УКРАИНЫ
}

\author{
А. П. Шматенко ${ }^{1}$, М. В. Белоус ${ }^{1}$, Т. В. Приходько ${ }^{1}$ А. В. Галан ${ }^{1}$, В. В. Трохимчук², Д. В. Дроздов ${ }^{1}$, \\ Н. А. Тахтаулова ${ }^{1}$
}

Украинская военно-медицинская академия ${ }^{1}$ Киев

Национальная медицинская академия последипломного образования имени П. Л. Шупика², Киев

maryvictory@ukr.net

Целью работы. Исследование этапов становления и развития системы военно-медицинского снабжения в контексте истории становления и развития Вооружённых Сил Украины.

Материалы и методы. Для достижения поставленной цели исследования проведен обзор отечественных научных источников и действующей нормативно-правовой базы. Во время выполнения исследования были использованы методы инорормационного поиска, систематизации, контент-анализа, сравнения и обобщения.

Результаты и обсуждение. При проведении исследования этапов становления и развития системы военномедицинского снабжения в контексте истории создания и развития Вооружённых Сил Украины установлено, что на момент создания Вооружённых Сил Украины военно-медицинская служба и система медицинского снабжения создавалась с использованием подходов Советской Армии. Принятие оборонной доктрины, изменение экономических основ в стране и ограниченность ресурсов обусловили переход к медицинскому обеспечению и снабжению медицинской техникой и имуществом по территориальному принципу.

Это, в свою очередь, требовало сокращения численности как Вооружённых Сил Украины, так и медицинской службы до оптимального количества. Определено, что недостаточность бюджетного фринансирования на протяжении всех лет существования Вооруженных Сил Украины не позволила в полном объёме построить эффективную модель медицинского снабжения и провести техническое переоснащение медицинской службы.

Проведённый ретроспективный анализ эволюции органов управления медицинской службой Вооруженных Сил Украины показал, что в периоды 1991 - 1994 гг. и 2005 - 2007 гг. было дублирование управленческой фрункции в отношении медицинского обеспечения в Министерстве обороны Украины и Генеральном штабе Вооруженных Сил Украины. При этом в период с 1998 - 2005 гг. управление медицинским обеспечением осуществлял единственный орган управления, что способствовало более эфрфективному решению вопросов медицинского обеспечения.

Выводы. В статье проведено исследование этапов становления и развития системы военно-медицинского снабжения в контексте истории создания и развития Вооруженных Сил Украины. Также определено, что на современном этапе реализуется принципединого органауправления медицинской службой, отвечающей стандартам HATO. На сегодня развитие системы медицинского снабжения Вооруженных Сил Украины ориентировано на интеграцию в единую эффрективную систему логистического обеспечения Вооруженных Сил Украины, которая фрункционирует в соответствии с нормами и стандартами Альянса.

Таким образом, для выбора научно обоснованной модели военно-медицинского снабжения в современных реалиях, необходимо обобщение исторического опыта фрормирования системы снабжения медицинским имуществом Вооруженных Сил Украины. Предметом нашего дальнейшего исследования является определение эволюционных этапов развития управления потоковыми процессами в системе медицинского снабжения Вооруженных Сил Украины.

Ключевые слова: Вооруженные Силы Украины; система медицинского снабжения; этапы развития и ресрормирования.

ISSN 2312-0967. Pharmaceutical review. 2019. № 3 
Фармацевтичний менеджмент, маркетинг та логістика Pharmaceutical management, marketing and logistics

\section{Список літератури}

1. Про рішення Ради національної безпеки і оборони України від 02.09.2015 р. «Про нову редакцію Воєнної доктрини України» : Указ Президента України від 24.09.2015 № 555/2015 [Електронний ресурс]. - Режим доступу : https://www.president.gov. ua/documents/5552015-19443.

2. Муженко В. М. Перспективні напрямки розвитку Збройних Сил в умовах суттєвих змін у воєннополітичній ситуації навколо України на період до 2020 р. / В. М. Муженко // Наука і оборона. - 2015. - № 3-4. - C. 22 - 27.

3. Концептуальні засади фрормування сучасної системи лікувально-евакуаційного забезпечення військ (сил) у контексті формування нового обрису Збройних Сил України (повідомлення друге) / А. В Верба, Е. М. Хорошун, В. І. Стриженко [та ін.] // Військова медицина України. - 2016. - Т. 16, № 2. - C. $5-14$.

4. Воєнна історія [Електронний ресурс]. - Режим доступу : http://www.mil.gov.ua/ministry/istoriya.html.

5. Лазоркін В. Збройні Сили України: 1991 - 2011 [Електронний ресурс] / В. Лазоркін. - Режим доступу : http://universum.Iviv.ua/previous-site/journal/2011/6/ lazork.htm.

6. Білий В. Я. Стратегія розвитку військової медицини в Україні / В. Я. Білий // Військова медицина України. -2001 . - № 1. - С. 9 - 18.

7. Бадюк М. І. Основні принципи формування системи медичного забезпечення військ за територіальним принципом / М. І. Бадюк // Військова медицина України. - 2008. - Т. 8, № 1. - С.5-12.

8. Про затвердження Програми розвитку системи медичного забезпечення ЗСУ на $2006-2011$ роки :

\section{References}

1. Ukaz Prezydenta Ukrainy № 555/2015 Pro rishennia Rady natsionalnoi bezpeky i oborony Ukrainy vid 02.09.2015 r. "Pro novu redaktsiiu Voiennoi doktryny Ukrainy". Available from: https://www.president.gov.ua/ documents/5552015-19443. Ukrainian.

2. Muzhenko VM. [Perspective directions of development of the Armed Forces in conditions of significant changes in the military-political situation around Ukraine for the period until 2020]. Nauka i oborona. 2015;3-4: 22-7. Ukrainian.

3. Verba AV, Khoroshun EM, Stryzhenko VI, Bulakh OYU, Hulpa VS. [Conceptual bases of forming of modern curatively-evacuation system of providing of troops are in context of forming of new look of the Armed Forces of Ukraine (the second message)]. Viiskova medytsyna Ukrainy. 2016;2(16): 5-14. Ukrainian.

4. Voienna istoriia. Available from: http://www.mil.gov.ua/ ministry/istoriya.html. Ukrainian.

5. Lazorkin V. Zbroini Syly Ukrainy: 1991-2011. Available from: http://universum.Iviv.ua/previous-site/journal/2011/6/lazork.htm. Ukrainian.

6. Bilyi VYA. [Strategy of development of military medicine in Ukraine]. Viiskova medytsyna Ukrainy. 2001;1: 9-18. Ukrainian. наказ МОУ від 24.11.2006 р. № 678 [Електронний ресурс]. - Режим доступу : http://www.mil.gov.ua.

9. Положення про організацію та здійснення медичного забезпечення Збройних Сил України за територіальним принципом : наказ МОУ від 10.05.2007 р. № 235. - К. : МО України, 2007. - 17 с.

10. Гульпа В. С. Передумови реформування системи медичного постачання за територіальним принципом, сучасний стан та проблеми / В. С. Гульпа // Військова медицина України. - 2011. - Т. 11, № 2. - C. $79-85$.

11. Шматенко О. П. Історичний шлях розвитку організації забезпечення військ медичним майном : навч. посіб. / О. П. Шматенко, А. М. Соломенний, О.В.Галан. - К. : УВМА, 2018. - $100 \mathrm{c}$.

12. Про затвердження Основних положень логістичного забезпечення Збройних Сил України : наказ МОУ від 11.10.2016 р. № 522 [Електронний ресурс]. - Режим доступу : http://www.mil.gov.ua/ministry/normativnopravova-baza/nakazi-ministra-oboroni-ukraini/nakaziministerstva-oboroni-ukraini-za-2016-rik.html.

13. Державна програма розвитку Збройних Сил України на період до 2020 року [Електронний ресурс]. - Режим доступу : http://www.mil.gov.ua/content/ oboron_plans/22017-06-16_National-program-2020_ uk.pdf.

14. Про затвердження Концепції програми розвитку системи медичного забезпечення Збройних Сил України на період до 2020 року : наказ МОУ від 26.07.2017 р. № 389 [Електронний ресурс]. - Режим доступу : http://www.mil.gov.ua/ministry/normativnopravova-baza/nakazi-ministra-oboroni-ukraini/ministerstva-oboroni-ukraini.html.

7. Badiuk MI. [Basic principles of the formation of the medical support system of troops by the territorial principle]. Viiskova medytsyna Ukrainy. 2008;1(8): 5-12. Ukrainian.

8. Nakaz MOU vid 24.11.2006 r. №678 "Pro zatverdzhennia Prohramy rozvytku systemy medychnoho zabezpechennia ZSU na 2006 - 2011 roky". Available from: http://www.mil.gov.ua. Ukrainian.

9. Nakaz MOU vid 10.05.2007 r. № 235 "Polozhennia pro orhanizatsiiu ta zdiisnennia medychnoho zabezpechennia Zbroynykh Syl Ukrainy za terytorialnym pryntsypom". Kyiv: MO Ukrainy; 2007. Ukrainian.

10. Hulpa VS. [Prerequisites for reforming the medical supply system of according to the territorial principle, the current state and problems]. Viiskova medytsyna Ukrainy. 2011;2(11): 79-85. Ukrainian.

11. Shmatenko OP, Solomennyi AM, Halan OV. Istorychnyi shliakh rozvytku orhanizatsii zabezpechennia viisk medychnym mainom [Historical way of development of the organization of providing troops with medical supplies]. Kyiv: UVMA; 2018. Ukrainian.

12. Nakaz MOU vid 11.10.2016 r. № 522 "Pro zatverdzhennia Osnovnykh polozhen lohistychnoho zabezpechen-

ISSN 2312-0967. Фармацевтичний часопис. 2019. № 3 
Фармацевтичний менеджмент, маркетинг та логістика Pharmaceutical management, marketing and logistics

nia Zbroinykh Syl Ukrainy". Available from: http://www. mil.gov.ua/ministry/normativno-pravova-baza/nakaziministra-oboroni-ukraini/nakazi-ministerstva-oboroniukraini-za-2016-rik.html. Ukrainian.

13. Derzhavna prohrama rozvytku Zbroynykh Syl Ukrainy na period do 2020 roku. Available from: http://www.mil. gov.ua/content/oboron_plans/22017-06-16_National- program-2020 uk.pdf. Ukrainian.

14. Nakaz MOU vid 26.07.2017 r. № 389 “Pro zatverdzhennya Kontseptsii prohramy rozvytku systemy medychnoho zabezpechennia Zbroinykh Syl Ukrainy na period do 2020 roku". Available from: http://www.mil.gov.ua/ministry/normativno-pravova-baza/nakazi-ministra-oboroniukraini/ministerstva-oboroni-ukraini.html. Ukrainian.

\section{Відомості про авторів:}

Шматенко О. П. - д. фрармац. н., професор, заслужений працівник фрармації України, полковник медичної служби Збройних Сил України, начальник кафедри військової фрармації, Українська військово-медична академія, Київ, Україна. E-mail: mavad@ukr.net, ORCID 0000-0002-6145-460X

Білоус М. В. - канд. фрармац. н., доцент кафедри військової фрармації, Українська військово-медична академія, Київ, Україна. E-mail: maryvictory@ukr.net, ORCID 0000-0002-4370-8813

Приходько Т. В. - канд. фармац. н., доцент, підполковник медичної служби Збройних Сил України, доцент кафедри військової фрармації, Українська військово-медична академія, Київ, Україна. E-mail: tetianavf@ukr.net, ORCID 00000003-3197-2120

Галан О. В. - старший викладач кафедри військової фрармації, полковник медичної служби у відставці, заслужений працівник фрармації України, Українська військово-медична академія, Київ, Україна. E-mail: galan1968@ukr.net, ORCID 0000-0002-0005-5699

Трохимчук В. В. - Д. фрармац. н., професор, заслужений працівник освіти України, декан медико-профрілактичного і фрармацевтичного фракультету, Національна медична академія післядипломної освіти імені П. Л. Шупика, Київ, Україна. E-mail: tvvo@ukr.net, ORCID 0000-0001-9994-8931

Дроздов Д. В. - старший викладач кафредри військової фрармації, Українська військово-медична академія, Київ, Україна. E-mail: drozdova82@ukr.net, ORCID 0000-0002-7769-750X

Тахтаулова Н. О. - канд. фрармац. н., доцент кафедри військової фрармації, Українська військово-медична академія, Київ, Україна. E-mail: Tahtaulova@i.ua, ORCID 0000-0003-3705-8110

\section{Information about the authors:}

Shmatenko O. P. - DS (Pharmacy), Professor, Honored Pharmacist of Ukraine, Colonel MED, head of the Military Pharmacy Department, Ukrainian Military Medical Academy, Kyiv, Ukraine. E-mail: mavad@ukr.net, ORCID 0000-00026145-460X

Bilous M. V. - PhD (Pharmacy), associate professor, the Military Pharmacy Department, Ukrainian Military Medical Academy, Kyiv, Ukraine. E-mail: maryvictory@ukr.net, ORCID 0000-0002-4370-8813

Prikhodko T. V. - PhD (Pharmacy), Lieutenant-colonel MED, associate professor, the Military Pharmacy Department, Ukrainian Military Medical Academy, Kyiv, Ukraine. E-mail: tetianavf@ukr.net, ORCID 0000-0003-3197-2120

Galan O. V. - Honored Pharmacist of Ukraine, senior lecturer of the Military Pharmacy Department, Ukrainian Military Medical Academy, Kyiv, Ukraine. E-mail: galan1968@ukr.net, ORCID 0000-0002-0005-5699

Trokhymchuk V. V. - DS (Pharmacy), Professor, Honored Worker of Education of Ukraine, head of the Medical and Prophylactic and Pharmaceutical Faculty, National Medical Academy of Postgraduate Education, Kyiv, Ukraine. E-mail: tvvo@ukr.net, ORCID 0000-0001-9994-8931

Drozdov D. V. - senior lecturer of Military Pharmacy Department, Ukrainian Military Medical Academy, Kyiv, Ukraine. E-mail: drozdova82@ukr.net, ORCID 0000-0002-7769-750X

Takhtaulova N. O. - PhD (Pharmacy), associate professor, the Military Pharmacy Department, Ukrainian Military Medical Academy, Kyiv, Ukraine. E-mail: Tahtaulova@i.ua, ORCID 0000-0003-3705-8110 